\title{
A Small Ultra-wideband Circular Patch Antenna with Band-notched Characteristic
}

\author{
L. Aguni ${ }^{1}$, S. Chabaa ${ }^{2}$, S. Ibnyaich ${ }^{1}$, A. Zeroual ${ }^{1}$ \\ ${ }^{1}$ Department of physics, Cadi Ayyad University Faculty of Sciences, Semlalia Marrakesh, Morocco \\ 2 Industrial Engineering Department, National School of Applied Sciences, Ibn Zohr University, Agadir, Morocco
}

(Received 14 February 2021; revised manuscript received 15 April 2021; published online 20 April 2021)

\begin{abstract}
In this paper, we propose to design a circular microstrip patch antenna printed on FR4-epoxy dielectric substrate. The designed antenna will be able to operate for UWB (ultra-wideband) applications. The Federal Communication Commission (FCC) has approved the use of the frequency spectrum from 3.1 to 10.6 GHz for UWB applications. The proposed antenna has a large bandwidth, which covers the frequency band of $3.85-12.38 \mathrm{GHz}$ except the notch band of 5.1-6 GHz, which is the main characteristic of the presented antenna. This feature allows to avoid interferences with applications operating at this band such as WLAN, IEEE 802.11a, and HIPERLAN/2. Besides these characteristics, the designed antenna has a simple structure and small sizes of $24 \times 14 \times 0.8 \mathrm{~mm}^{3}$. The principal operating parameters of the antenna like VSWR, radiation pattern, radiation efficiency, and group delay are simulated using both HFFS and CST electromagnetic simulators. The variation of the group delay of the antenna in the frequency band from 3.85 to $12.38 \mathrm{GHz}$ is almost constant at around $1.25 \mathrm{~ns}$ and presents small fluctuations, except in the vicinity of the 5.1-5.8 GHz notch band whose group delay drops from $1.5 \mathrm{~ns}$ to $-2 \mathrm{~ns}$. These features make the proposed antenna a better device for UWB applications.
\end{abstract}

Keywords: Notch band, Patch antenna, UWB, VSWR, Group delay.

DOI: 10.21272/jnep.13(2).02032

PACS numbers: 84.40.Ba, 06.30.Ft

\section{INTRODUCTION}

Because of their many attractive characteristics, such as small size, lightweight, and low fabrication cost, microstrip patch antennas have garnered the interest of many researchers and designers. These antennas can be used for various applications like GPS, WLAN/WIMAX, UWB etc. A simple microstrip patch structure has a radiating patch of different geometries, such as rectangular, triangular, circular, or square. The radiating patch is etched on the top of a dielectric substrate. Ultra-wideband (UWB) antennas have attracted interest particularly due to their simple feed and ability to cover a wide bandwidth. The trend is to use single antenna devices, which satisfy the notch band characteristic instead of using additional elements like filters, which can complicate the antenna design.

Generally, a patch antenna should be less bulky with a simple structure, a low profile, and compatible with printed circuits (Printed Circuit Board, PCB) $[1,2]$. In addition to these characteristics, a patch antenna designed for UWB technology must meet certain requirements [3, 4]. First, an UWB antenna should occupy a frequency spectrum from 3.1 to $10.6 \mathrm{GHz}$ with at least a bandwidth of $500 \mathrm{MHz}$. Second, the antenna's operating performance such as radiation pattern, gain, and efficiency should be satisfactory. Also, it is preferable that an UWB antenna has one or more notch bands to avoid interferences with other applications occupying a part of the UWB frequency band. Finally, it is important that an UWB antenna transmits a signal with minimal distortion with a constant group delay over the entire frequency band to avoid any complexity of detection at the receiver.

Consequently, in the literature many researchers have focused their attention on the designing of a microstrip patch antenna that meets the UWB require- ments. In [5], a CPW-fed U-type monopole antenna is proposed for UWB operations. However, the proposed antenna does not have a notch band. In [6], an inverted T-shaped antenna for UWB applications with dual band-notch function is considered. According to [7], a compact UWB monopole antenna with a band-notched characteristic is presented. The band-notched characteristic is achieved by inserting a U-shaped slot in a half-elliptical ring-radiating patch. The authors of [8] present an UWB antenna with triple notched band. The triple band-notched characteristics are obtained by etching two C-shaped slots on a radiating patch and a pair of symmetric C-shaped slots on the ground plane. An UWB antenna with triple notched band, as elaborated in the paper [9], is achieved using hollow-crossloop resonator. In [10], a band-notched UWB printed antenna with a pair of inverted L-shaped slots inserted on the ground plane is presented.

In this paper, we achieved the band-notched characteristic by inserting a slit ring in a circular patch. The UWB feature is obtained by optimizing the parameters $(a, b$ and $g$ ) of the slit ring and the dielectric permittivity. The presented antenna is designed with a partial ground plane to improve the impedance bandwidth. The simulated VSWR shows that the proposed UWB antenna covers a wide band ranging from 3.1 to 10.6 GHz. In the following sections, various results will be simulated and discussed.

The main challenge of the designed antenna is:

- To achieve a simpler structure to avoid complexity in the fabrication process.

- To achieve a wide impedance bandwidth suitable for UWB applications.

- To achieve band-notched characteristic to prevent interferences.

- To reduce the signal distortion by realizing a constant group delay. 


\section{DESIGNED ANTENNA AND THEORETICAL FORMULA}

The proposed antenna consists of a circular patch, a ground plane, a feed line, and a dielectric substrate. In the circular patch, we inserted a slit ring characterized by the dimensions: inner radius $a$, outer radius $b$, and gap $g$. The partial ground plane has a length $l_{g}$ and a width $\omega_{g}$. A 50-ohm feed line of length $l_{f}$ and width $\omega_{f}$ was used as a transmission line to excite the patch antenna by RF energy. The patch, the ground plane, and the feed line consist of copper with a thickness $t=0.035 \mathrm{~mm}$ as the main material. The dielectric substrate is FR4-epoxy with dielectric permittivity $\varepsilon_{r}=4.3$, loss tangent $\tan \delta=0.025$, length $L=24 \mathrm{~mm}$, width $W=14 \mathrm{~mm}$, and height $h=0.8 \mathrm{~mm}$. The geometry of the proposed antenna is depicted in Fig. 1.

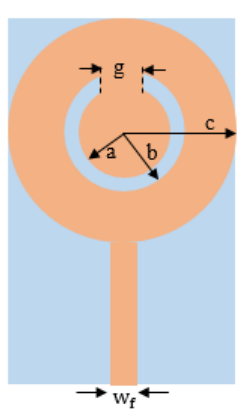

Front view

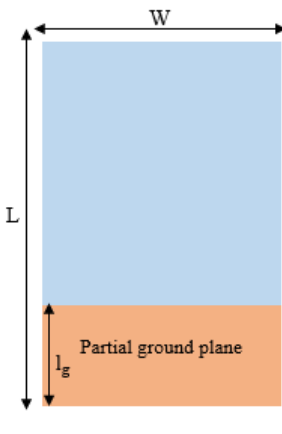

Rear view

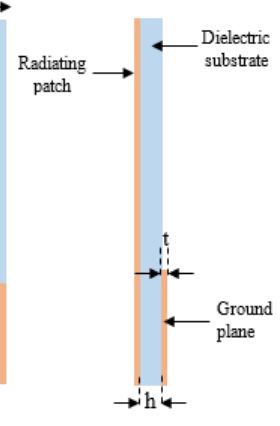

Side view
Fig. 1 - Proposed UWB antenna

The antenna feed impedance is chosen to be $50 \mathrm{ohm}$ Theoretically, to obtain a good impedance adaptation, the width of the feed line $w_{f}$ is calculated by [11]:

$w_{f}=\frac{h}{\pi}\left[A-1-\ln (2 A-1)+\frac{\varepsilon_{\text {eff }}-1}{2 \varepsilon_{\text {eff }}}\left[\ln (A-1)+0.39-\frac{0.61}{\varepsilon_{\text {eff }}}\right]\right]$,

where $\varepsilon_{\text {eff }}=\frac{\varepsilon_{r}+1}{2}, \quad A=\frac{377 \pi}{2 Z_{0} \sqrt{\varepsilon_{\text {eff }}}}$ and $Z_{0}=50 \Omega$.

We can also calculate the band-notched frequency generated by the slit ring inserted in the circular patch according to the following formula $[12,13]$ :

$$
f_{N B}=\frac{c}{2 L_{N B} \sqrt{\varepsilon_{e f f}}},
$$

where $c$ is the speed of light $\left(c=3 \times 10^{8} \mathrm{~m} / \mathrm{s}\right)$ and $L_{N B}$ is the length of the slit ring printed on the circular patch

$$
L_{N B}=2 \pi a+2(b-a)-g,
$$

while $\varepsilon_{e f f}$ is the effective dielectric substrate, $\varepsilon_{\text {eff }}=\frac{\varepsilon_{r}+1}{2}$.

\section{PARAMETRIC STUDY}

We can conclude from the formulas cited above (expressions (2) and (3)), that the notch frequency depends mainly on the dimensions of the slit ring, namely $a, b$, and $g$ and the dielectric permittivity $\varepsilon$. In order to observe the effect of these parameters on the notch frequency, we performed a parametric study by varying the parameters $\left(a, b, g\right.$, and $\left.\varepsilon_{r}\right)$ and observing the VSWR vs frequency response (Fig. 2). We can notice from Fig. 2a that with an increase in the inner radius of the slit ring $a$ from 1.41 to $3.81 \mathrm{~mm}$, the central frequency slowly disappears and shifts to lower frequencies. At the same time, by increasing the outer radius of the slit ring (parameter $b$ ), as depicted in Fig. 2b, the notch frequency shifts to lower frequencies, whereas the VSWR increases.

The VSWR and the band-notched frequency are also affected by the variation of the gap $g$. By changing the gap $g$ from $1.42 \mathrm{~mm}$ to $3.82 \mathrm{~mm}$, the central frequency moves slightly to higher frequencies as illustrated in Fig. 2c. The other parameter which affects the VSWR is the electrical parameter $\varepsilon_{r}$. For this reason, we took three different dielectric substrates, namely Arlon DiClad 880 (tm), FR4-epoxy and Taconic RF-60 (tm), which have $2.2,4.3$, and 6.15 as a dielectric permittivity respectively. As given in Fig. $2 \mathrm{~d}$, the notch band frequency takes three different values 4.8, 5.5 and 6.5 GHz.

By exploiting these results, we can notice that the modification of the parameters $a, b, g$, and $\varepsilon$ r directly affects the VSWR and the notch band frequency. The appropriate values used during the process of designing the antenna are $3.01,3.98,3.02$ and $4.3 \mathrm{~mm}$ for $a, b, g$, and $\varepsilon_{r}$, respectively.

\section{RESULTS AND DISCUSSION}

The VSWR result for the proposed antenna and the basic antenna, which consists of a circular patch without a slit ring, is plotted using the HFSS simulator. From the VSWR graph illustrated in Fig. 3, we notice that the proposed antenna has a VSWR $\leq 2$ in the band ranging from 3.85 to $12.38 \mathrm{GHz}$, except the band of 5.1$6 \mathrm{GHz}$, where VSWR $>2$, which is the condition for obtaining the band rejection and therefore preventing interferences with other applications such as WLAN, IEEE 802.11a, and HIPERLAN/2, while the basic antenna does not expose any notch band.

The far-field radiation pattern of the proposed antenna is also studied at different frequencies, whether in the elevation plane $x o z$ ( $E$-plane) or the azimuthal plane xoy ( $H$-plane). For this purpose, we plotted the coand cross-polarization radiation patterns at 3.5, 5.5 and $10 \mathrm{GHz}$ frequencies as shown in Fig. 4. In the elevation plane, we notice that the antenna presents a bidirectional radiation diagram for all operating frequencies, while we obtain omnidirectional radiation in the azimuthal plane. We can also observe that the microstrip patch presents minimal cross-polarized radiation.

The radiation efficiency of an antenna is a ratio between the power delivered to the antenna and the power radiated by the antenna. The efficiency cannot be practically $100 \%$, as it is affected by losses in the structure of the antenna itself such as conductive losses, dielectric losses, and reflections due to the mismatch between the antenna and the feed line. For this reason, we determine the total efficiency which takes into account all these losses. We note that, as depicted in Fig. 5, 


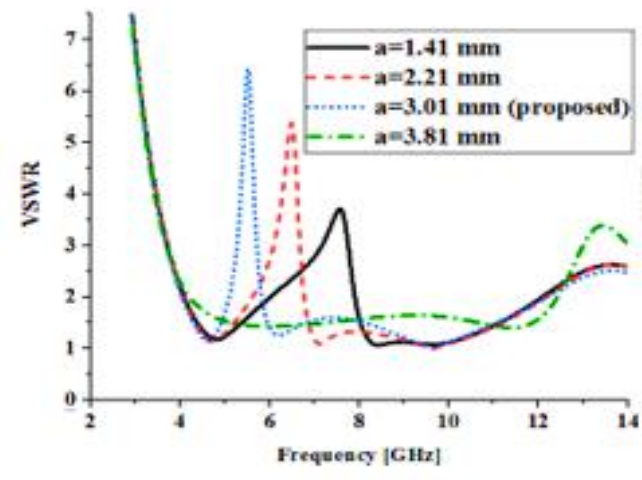

(a)

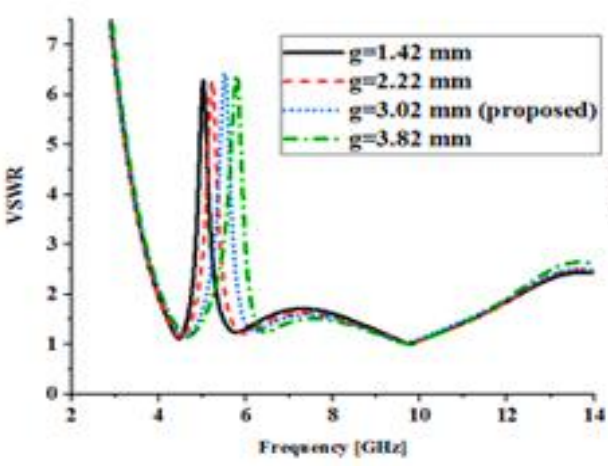

(c)

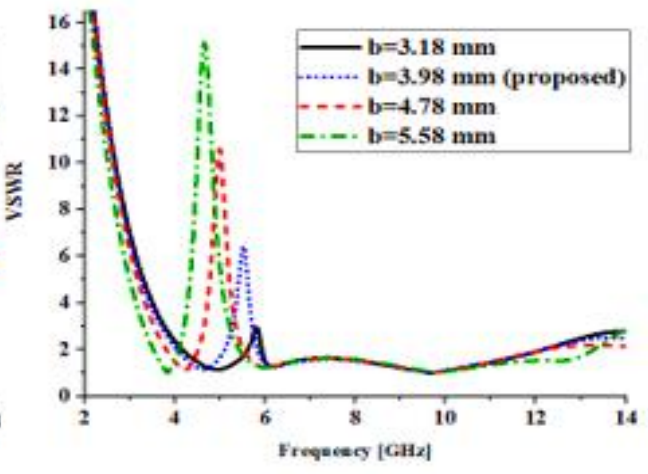

(b)

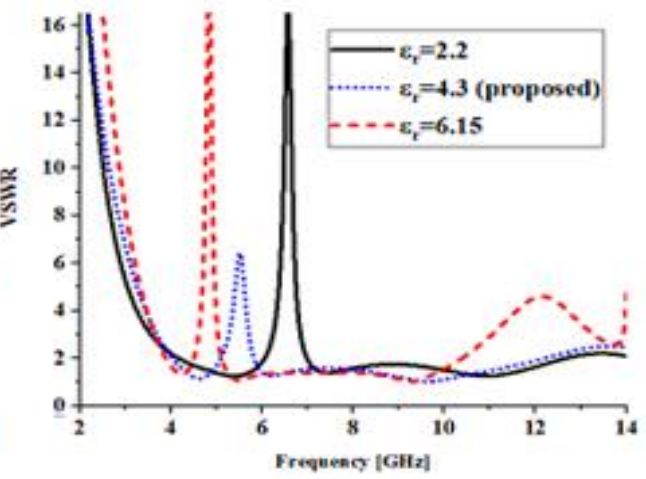

(d)

Fig. 2 - Parametric study: (a) parameter $a$, (b) parameter $b$, (c) parameter $g$, (d) parameter $\varepsilon_{r}$

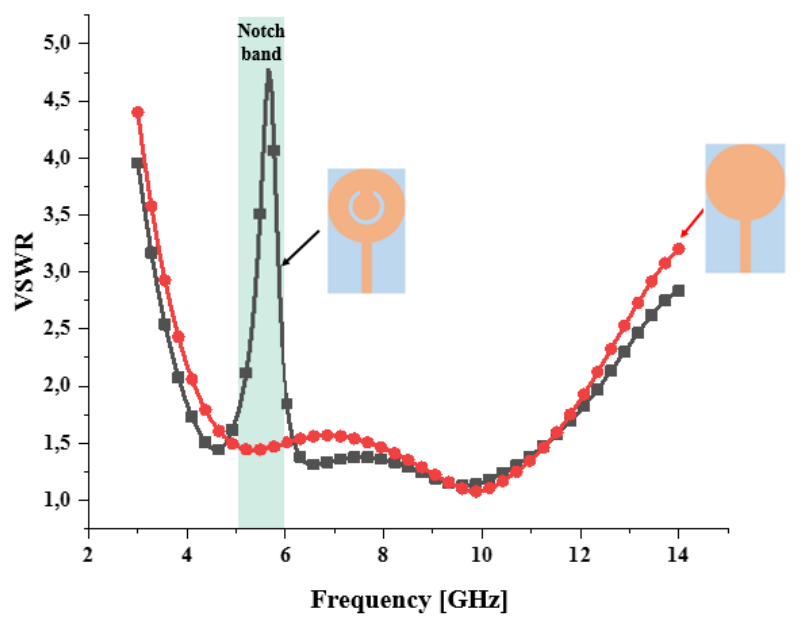

Fig. 3 - VSWR vs frequency of the proposed antenna

the UWB antenna designed has a total efficiency of around $70 \%$ over the entire frequency band except the notch band. A maximum total efficiency of around $85 \%$ is reached at a frequency of $4.6 \mathrm{GHz}$.

UWB communication systems require a smaller antenna with constant group delay [14]. This parameter is one of the important characteristics of the UWB antenna, which indicates the pulse distortion. Constant group delay is desirable, because it indicates how the UWB pulse will be transmitted and how it can be dis- torted or dispersed. Fig. 6 illustrates the group delay of the proposed UWB antenna. The variation of the group delay of the antenna on the frequency band from 3.85 to $12.38 \mathrm{GHz}$ is around $1.25 \mathrm{~ns}$ and presents small fluctuations, except in the vicinity of the $5.1-5.8 \mathrm{GHz}$ notch band, whose group delay drops from $1.5 \mathrm{~ns}$ to $-2 \mathrm{~ns}$. The results of Fig. 6 indicate that in the UWB band, except the notch band, the characteristics of the group delay are almost constant at around $1.25 \mathrm{~ns}$ either in the face-to-face configuration (Fig. 6a) or in the side-by-side configuration (Fig. 6b).

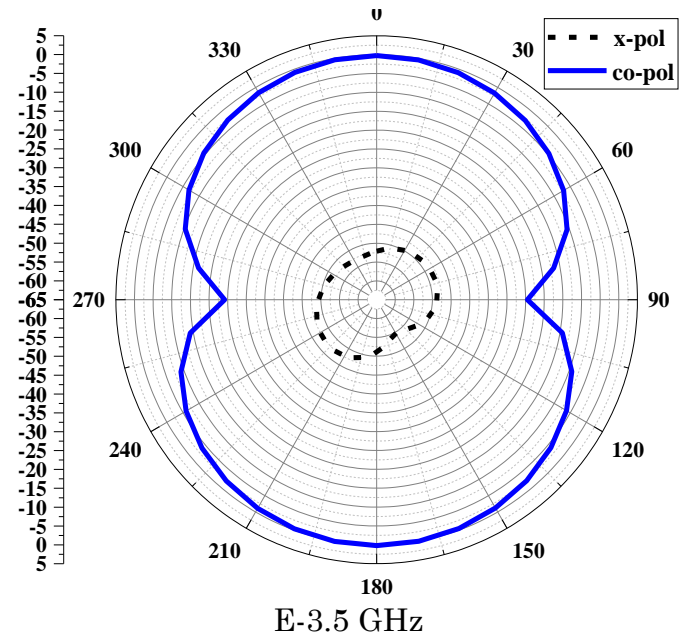




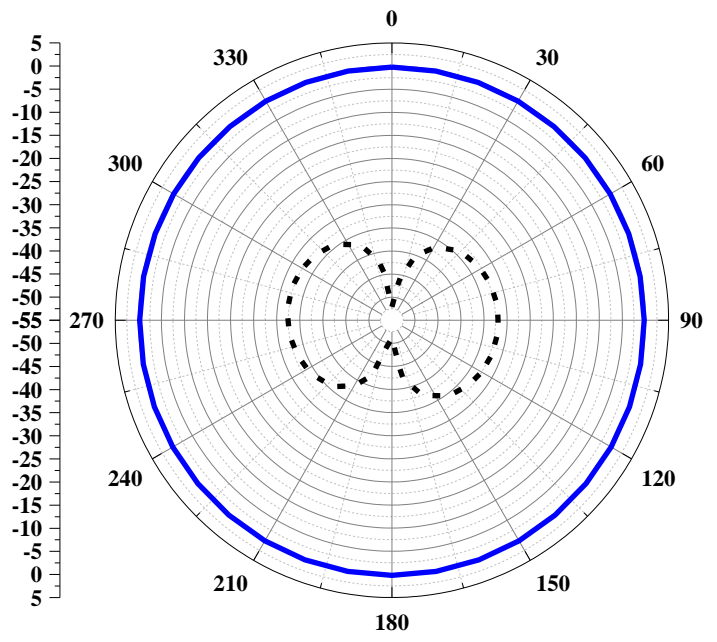

H-3.5 GHz

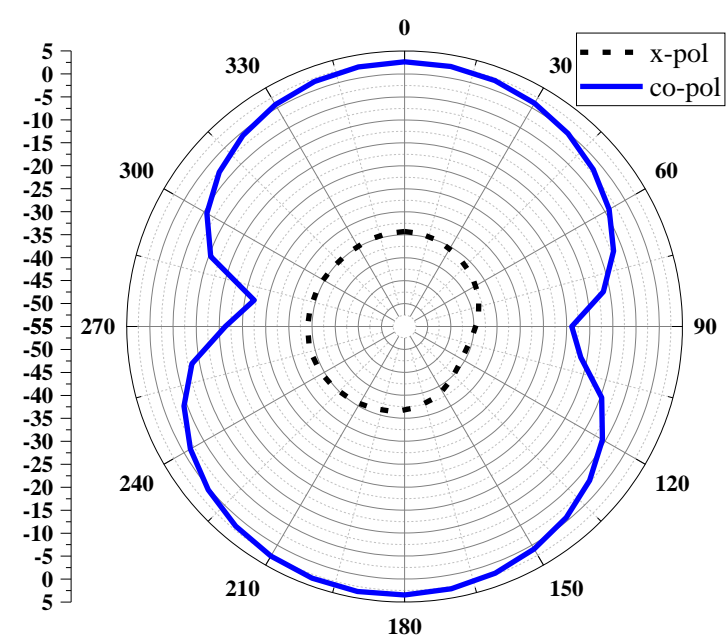

E-5.5 GHz

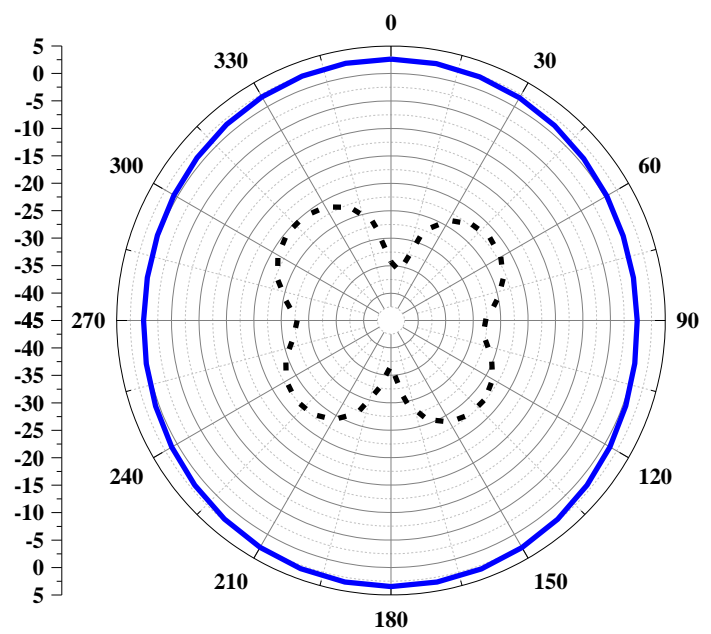

$\mathrm{H}-5.5 \mathrm{GHz}$

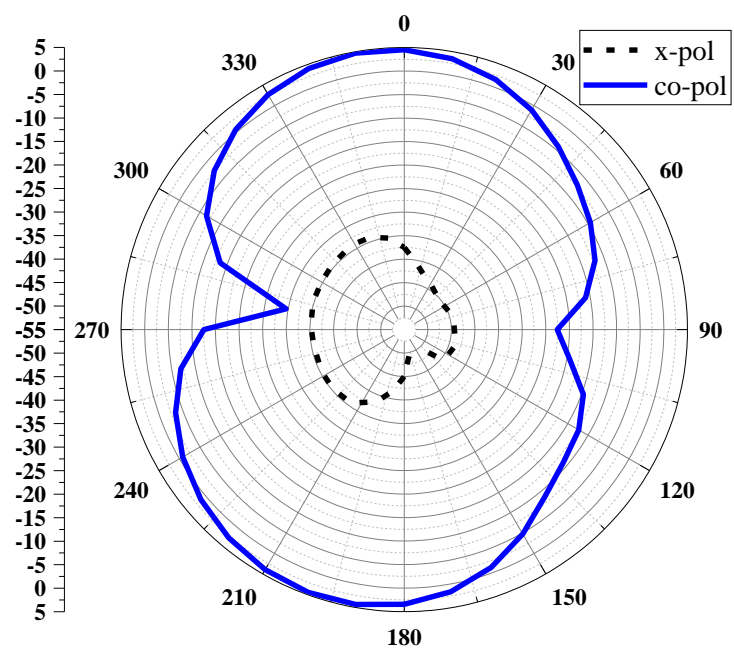

E-10 GHz

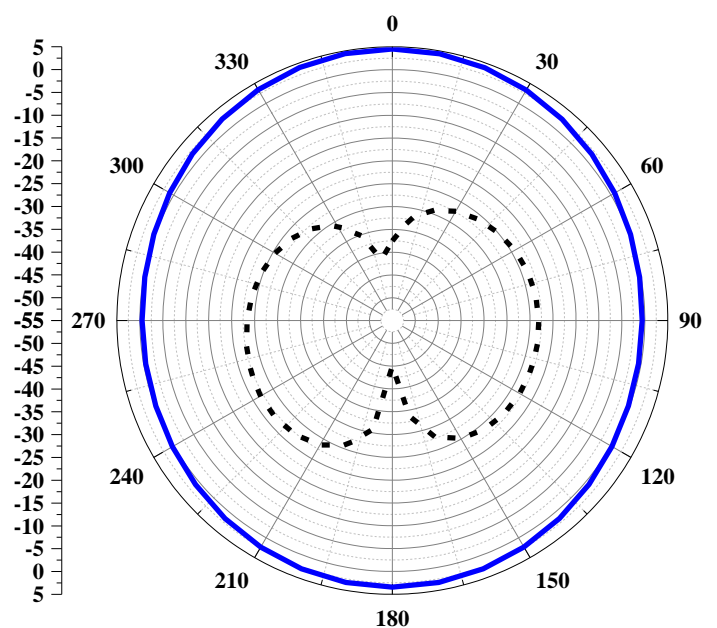

$\mathrm{H}-10 \mathrm{GHz}$

Fig. 4 - Simulated co- and cross-polarization radiation patterns at different frequencies

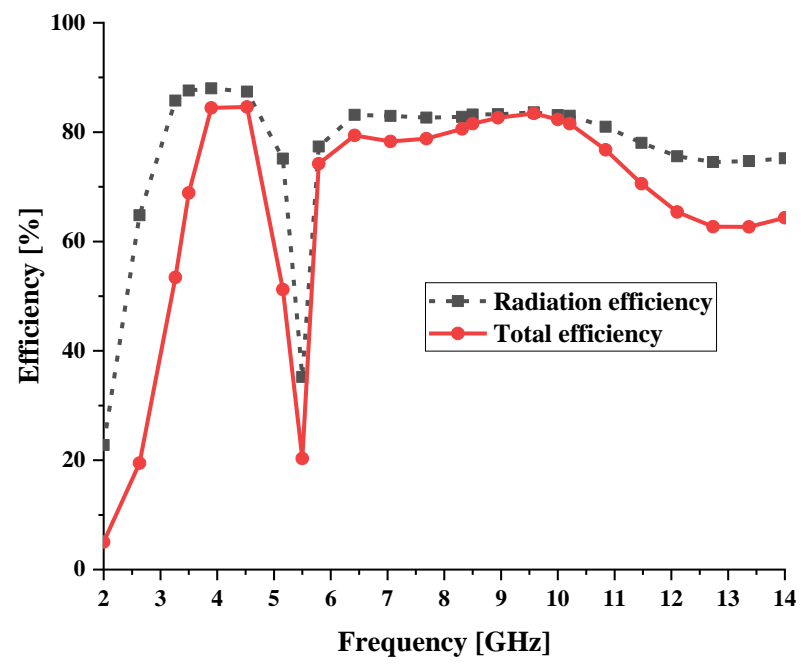

Fig. 5 - Simulated radiation efficiency of the proposed antenna 


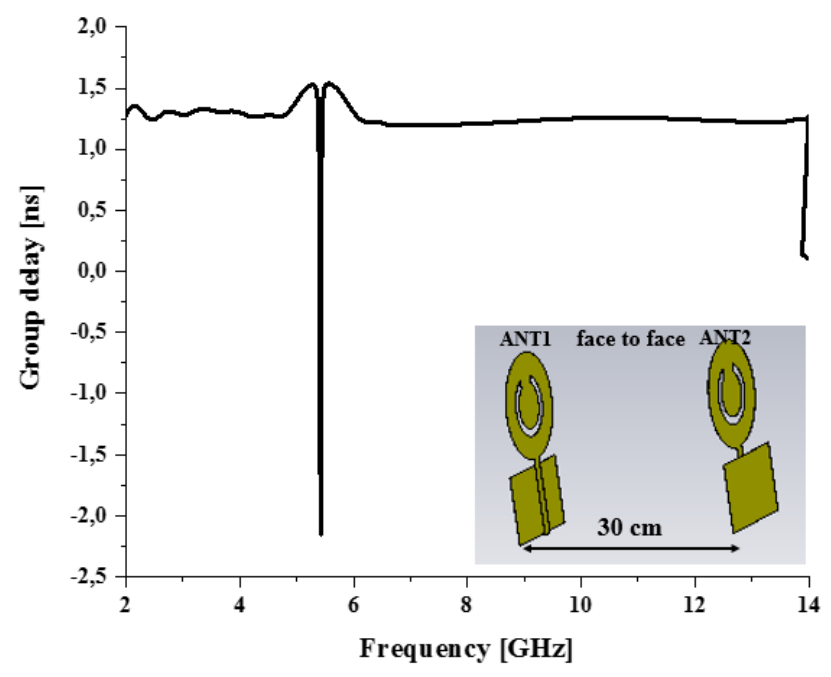

a

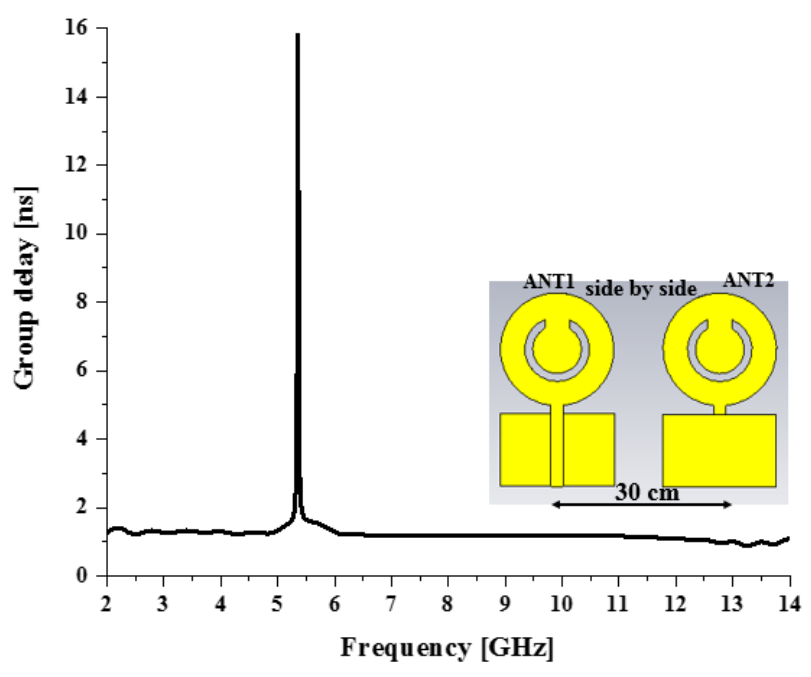

$\mathrm{b}$

Fig. 6 - Simulated group delay of the proposed antenna: (a) face-to-face configuration, (b) side-by-side configuration

In order to confirm the nature of the distortion of the input signal, the time domain of the proposed antenna is also determined and plotted in Fig. 7. Two configurations were taken into account, namely sideby-side configuration and face-to-face configuration. In these configurations, one antenna is used as a transmitting antenna, whereas the other is used as a receiving antenna. The distance between the two antennas is fixed at $30 \mathrm{~cm}$ to ensure that the antennas are in the far-field region of each other. By exploiting the normalized amplitude of the transmitted and received pulses in time domain, we conclude that the excitation signal presents low distortion in both configurations.

The input impedance simulation is illustrated in Fig. 8. In the operating band from 3.85 to $12.38 \mathrm{GHz}$, the real part of the input impedance varies between 45 and $79 \mathrm{Ohm}$. An impedance mismatch between the feed line and the antenna is observed in the notch band. According to the imaginary part of the input impedance, we observe that the behavior of the proposed antenna is inductive (positive polarity), while for other

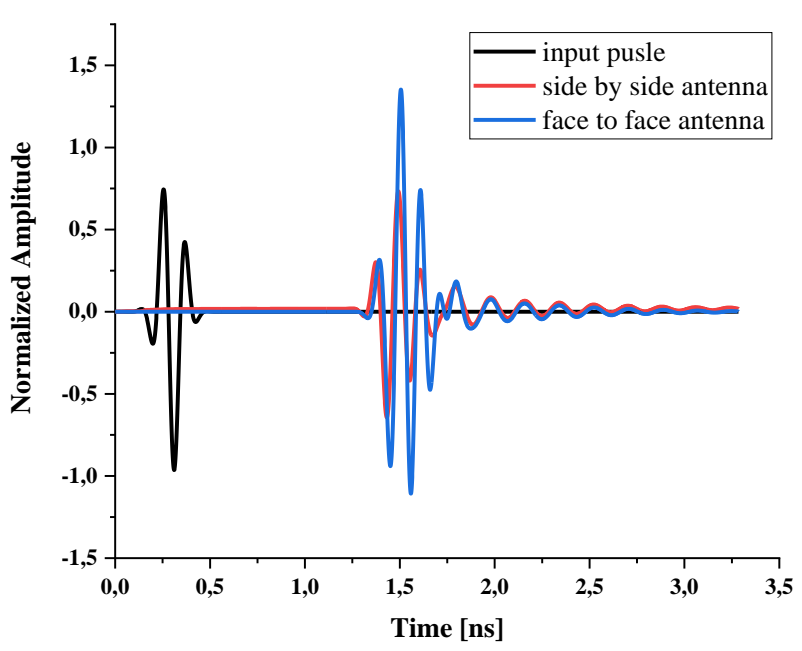

Fig. 7 - Normalized amplitude of transmitted and received pulses in time domain for the proposed antenna

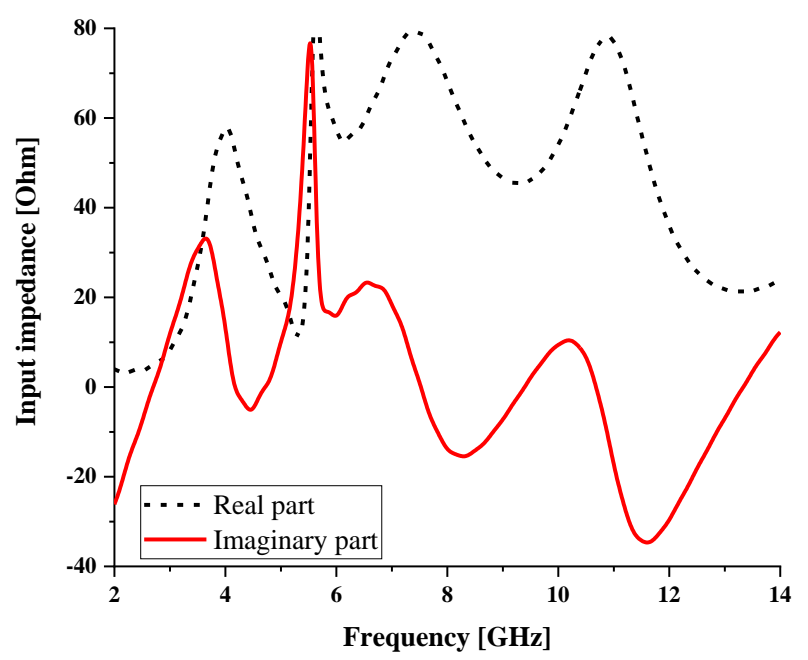

Fig. 8 - Simulated input impedance of the proposed antenna

frequencies it is capacitive (negative polarity).

A comparative study has been conducted between the proposed antenna and the antennas cited in literature as mentioned in Table 1 . The comparative result reveals that the proposed patch antenna with a small structure and a partial ground plane is a better device for UWB applications.

Table 1 - Comparative study

\begin{tabular}{|l|l|l|l|}
\hline Reference & \multicolumn{1}{|c|}{$\begin{array}{c}\text { Antenna size } \\
{\left[\mathbf{m m}^{3}\right]}\end{array}$} & $\begin{array}{c}\text { Frequency } \\
\text { range [GHz] }\end{array}$ & $\begin{array}{l}\text { Notch band } \\
{[\mathbf{G H z}]}\end{array}$ \\
\hline$[15]$ & $12.72 \times 17.22 \times 2$ & $3.1-10.6$ & - \\
\hline$[16]$ & $30 \times 30 \times 1.6$ & $2.94-12$ & $\begin{array}{l}3.3-3.6 \text { and } \\
5.7-6.2\end{array}$ \\
\hline$[17]$ & $26 \times 27 \times 1.6$ & $2.19-13.95$ & $4.67-6.21$ \\
\hline$[18]$ & $30 \times 30 \times 1$ & $2-15$ & $\begin{array}{l}2.5,3.5 \text { and } \\
5.5\end{array}$ \\
\hline$[19]$ & $33 \times 32 \times 1.5$ & $2-11$ & $\begin{array}{l}3.3-3.8 \text { and } \\
5.2-5.7\end{array}$ \\
\hline$[20]$ & $42 \times 53 \times 1$ & $3.1-10.6$ & $3.5-5.5$ \\
\hline$[21]$ & $30 \times 30 \times 1.6$ & $2.45-12.0$ & $\begin{array}{l}5.12-6 \text { and } \\
7.13-7.63\end{array}$ \\
\hline Proposed & $24 \times 14 \times 0.8$ & $3.85-12.38$ & $5.1-6$ \\
\hline
\end{tabular}




\section{CONCLUSIONS}

In this paper, we designed a simpler structure of a microstrip patch antenna for UWB applications. The proposed antenna is designed on a low-cost dielectric substrate FR4-epoxy with a thickness of about $0.8 \mathrm{~mm}$. A partial ground plane is introduced in the bottom part of the dielectric substrate to improve the VSWR (volt-

\section{REFERENCES}

1. C.A. Balanis, Antenna Theory, 811 (3 ${ }^{\text {rd }}$ Ed.) (John Wiley \& Sons: 2005).

2. R. Garg, P. Bhartia, I. Bahl, A. Itipiboon, Artech House, I, 13 (2000).

3. K.Y. Yazdandoost, R. Kohno, IEEE Commun. Mag. 42, S29 (2004).

4. K.P. Ray, Int. J. Antennas Propag. 2008, 713858 (2008).

5. X.C. Yin, C.L. Ruan, C.Y. Ding, J.H. Chu, Prog. Electromagn. Res. 2, $1(2008)$

6. M. Ojaroudi, N. Ojaroudi, IEEE T. Antenn. Propag. 62, 490 (2014).

7. X. Kang, H. Zhang, Z. Li, Q.-X. Guo, X. Zhang, J.-H. Wang, Y. Lamar Yang, Prog. Electromagn. Res. C 35, 23 (2012).

8. J Xu, G. Wang, Microw. Opt. Technol. Lett. 54, 2146 (2012).

9. Y. Liu, Z. Chen, S. Gong, Electron. Lett. 50, 728 (2014).

10. J.B. Jiang, Y. Song, Z.H. Yan, X. Zhang, W. Wu, Microw. Opt. Technol. Lett. 51, 260 (2009).

11. E.O. Hammerstad, Proc. Fifth Europ. Microwave Conf. 268 (1975). age standing wave ratio) and the impedance bandwidth. The presented antenna covers a large bandwidth from 3.85 to $12.38 \mathrm{GHz}$ except the notch band of 5.1$6 \mathrm{GHz}$. By inserting a slit ring in a circular patch and optimizing its dimensions using a parametric analysis, the band-notched feature is achieved. The proposed antenna presents good radiation patterns and minimal signal distortion.

12. T. Dissanayake, K.P. Esselle, IEEE Transact. Antennas Propag. 55, 3320 (2007).

13. A. Syed, W.A. Rabah, Sci. World J. 2016, 3560938 (2016).

14. M. Ghavami, L. B. Michael, R. Kohno (NJ: Wiley: 2007).

15. A. Singh, R.M. Mehra, and V.K. Pandey, Wirel. Pers. Commun. 1, 2485 (2020).

16. N. Sharma, S.S. Bhatia, V. Sharma, J.S. Sivia, Wirel. Pers. Commun. 111, 1977 (2020).

17. R.K. Garg, M.V.D. Nair, S. Singhal, R. Tomar, Microw. Opt. Technol. Lett. 62, 2537 (2020).

18. L. Asadpor and M. Rezvani, IETE J. Res. 1 (2018).

19. A. Sohail, K.S. Alimgeer, A Iftikhar, B. Ijaz, K. Wook Kim, W. Mohyuddin, Microw. Opt. Technol. Lett. 60, 925 (2018).

20. A. Khalilzadeh, A.E.C. Tan, K. Rambabu, AEUE-Int. J. Electron. Commun. 67, 433 (2013).

21. N. Sharma and S.S. Bhatia, Int. J. RF Microw. Comput. Aided Eng. 29 (2019).

\title{
Невелика надширокосмугова кругла патч-антена $з$ режекторною смугою
}

\author{
L. Aguni ${ }^{1}$, S. Chabaa ${ }^{2}$, S. Ibnyaich ${ }^{1}$, A. Zeroual ${ }^{1}$ \\ ${ }^{1}$ Department of physics, Cadi Ayyad University Faculty of Sciences, Semlalia Marrakesh, Morocco \\ ${ }^{2}$ Industrial Engineering Department, National School of Applied Sciences, Ibn Zohr University, Agadir, Morocco

\begin{abstract}
У роботі ми пропонуемо розробити круглу мікросмугову патч-антену, надруковану на FR4-
\end{abstract} \\ епоксидній діелектричній підкладщі. Розроблена антена зможе застосовуватися для UWB (надшироко- \\ смугових) додатків. Федеральна комісія зв'язку (FCC) схвалила використання частотного спектру від \\ 3,1 до 10,6 ГГц для UWB додатків. Запропонована антена має широкий діапазон частот пропускання, \\ який включає смугу частот 3,85-12,38 ГГц, за винятком режекторної смуги 5,1-6 ГГц, що є основною ха- \\ рактеристикою представленої антени. Ця особливість дозволяе уникнути втручання в додатки, які \\ працюють у цьому діапазоні, таких як WLAN, IEEE 802.11а та HIPERLAN/2. Окрім џих характеристик, \\ розроблена антена має просту структуру та невеликі розміри $24 \times 14 \times 0.8$ мм $^{3}$. Основні робочі параметри \\ антени, такі як VSWR, діаграма випромінювання, ефективність випромінювання та групова затримка, \\ моделюються за допомогою електромагнітних симуляторів HFFS та CST. Зміна групової затримки ан- \\ тени в смузі частот від 3,85 до 12,38 ГГц е майже постійною на рівні приблизно 1,25 нс і представляе \\ невеликі коливання, за винятком режекторної смуги 5,1-5,8 ГГц, групова затримка якої падає з 1,5 нс \\ до -2 нс. Ці особливості роблять запропоновану антену кращим пристроем для UWB додатків.
}

Ключові слова: Режекторний діапазон, Патч-антена, UWB, VSWR, Групова затримка. 